\title{
Criminal Liability of Investigators on Wrongful Accusations during Investigations
}

\author{
Dadi Purba ${ }^{1}$, Ediwarman $^{2}$, Madiasa Ablisar $^{3}$ \\ \{dadipurba88@students.usu.ac.id ${ }^{1}$, profediwarman25@gmail.com ${ }^{2}$, ablisar@yahoo.co.id ${ }^{3}$ \} \\ Universitas Sumatera Utara, Indonesia ${ }^{1,2,3}$
}

\begin{abstract}
Having the authority to designate a person as a suspect, investigators can potentially be subject to criminal charges if the designation is not following existing procedures. This results in the deviation of the original investigation objective. This study aims to find out how the criminal liability of investigators who make mistakes in determining suspects and other aspects related to the responsibility of investigators. The accountability of investigators that wrongfully determine a suspect is rarely challenged for various reasons, one of them being on duty. In this case, the investigator's actions are in the context of carrying out their duties only to be subject to the police code of ethics. The problems analyzed in this paper are the criminal liability of investigators who wrongfully determine suspects during the investigation process and efforts to eliminate further occurrences. This is normative juridical research using the descriptive analysis method, analyzing the application of criminal law through the criminal liability of investigators who commit procedural errors in using force during the investigation process. The results show that investigators who were wrongfully determining suspects can be held accountable if their actions are classified as criminal acts. Procedural errors committed by investigators can be eliminated by increasing the professionalism and quality of human resources and reforming regulations.
\end{abstract}

Keywords: Criminal Liability of Investigators, Determination of Suspects, Procedural Errors

\section{Introduction}

The Indonesian National Police is a subsystem of the Criminal Justice System (CJS). The CJS is a crime control system consisting of police, attorney, court, and correctional institutions [1]. In addition, it is also a system that exists in society to tackle crime, with the police being at its forefront [2]. According to Harkrisnowo [3], the police are the gatekeepers of the CJS. As a subsystem of the CJS, the police are assigned to carry out investigations that will produce police investigation reports (PIR) to be used as guidelines in settlement cases.

The police are often criticized due to their excessive use of force in carrying out their duties. Adji [4] argues that "such behavior has been internalized, especially in investigations in order to extract confessions from suspects". The investigation process is the most crucial stage in the CJS as the Police are authorized to use force. This can potentially cause administrative and procedural errors and abuse of authority that can cause both material and immaterial losses.

Deliberately or not, the amount of authority possessed by police investigators can potentially lead to the abuse of authority. An investigator may deliberately abuse his/her authority and tasks refuging behind the scope of their authority. 
John Emerich Edward Dalberg Acton, also known as Lord Acton, once made a statement that connected corruption with power, namely, "Power tends to corrupt, and absolute power corrupts absolutely" [5]. This can be applied to investigators; they have great authority and can very easily commit corruption. In this case, corruption is defined as "corrupt, evil, bad, broken, bribe, destroy, or change" [6] and abuse of authority in carrying out coercive measures during investigations.

Investigators are rarely held accountable for excessive use of force; most offenders are only processed through pretrial lawsuits. The objects are Article 77 and Article 95 of the Criminal Procedure Code, even though wrongful accusations have a significant impact.

Table 1. Pretrial Lawsuit Data with Suspect Determination from 2015 to 2020 in North Sumatra Regional Police

\begin{tabular}{|c|c|c|c|c|c|}
\hline No & Year & $\begin{array}{l}\text { Number of Lawsuit with } \\
\text { Suspect Determination }\end{array}$ & $\begin{array}{l}\text { Rejected } \\
\text { Lawsuit }\end{array}$ & $\begin{array}{l}\text { Accepted } \\
\text { Lawsuit }\end{array}$ & Note \\
\hline 1 & 2015 & 21 & 21 & 0 & \\
\hline 2 & 2016 & 24 & 22 & 2 & \\
\hline 3 & 2017 & 66 & 58 & 8 & \\
\hline 4 & 2018 & 48 & 44 & 4 & \\
\hline 5 & 2019 & 46 & 43 & 3 & \\
\hline 6 & 2020 & 61 & 60 & 1 & \\
\hline \multicolumn{2}{|c|}{ Total } & 266 & 248 & 18 & \\
\hline
\end{tabular}

The data in Table 1 shows, since 2015, after the enactment of the Constitutional Court Decision No. 21/PUU-XII/2014 on April 28, 2014, from 2015 to 2020, 266 pretrial lawsuit cases have been filed by the suspect to the district court of North Sumatra. Two hundred forty-eight files were rejected, and 18 files were accepted, which indicated wrongful accusations in determining the suspects.

Previously, it was challenging to make the investigator responsible for such a procedural error in determining the suspect. This is because, in Indonesia, legal formalities are prioritized in determining criminal liability based on mistakes in the form of dolus (a fraudulent address or trick used to deceive someone) and culpa (acts of commission and omission in both tort and contract cases). The legal rules contained in the Criminal Procedure Code that regulate the criminal liability of investigators using excessive force are inconsistent with legal norms, enabling these cases to be resolved through criminal proceedings and pretrial lawsuits. In addition, there is a legal vacuum in these cases as fines are prioritized. These inconsistencies and lack of legal norms are due to the legal-political system in Indonesia being dominated by the civil law system. This system was inherited from the Dutch and is internalized in the Indonesian legal system, especially in the liability of illegal acts. Civil law can be characterized as laws and regulations that have been codified [7]. This is in line with the opinion of KahnFreund [8], who stated that the success of transplantation depends mainly on the political system involved, while Legrand [9] and Seidman [10] view laws as culturally formed constructs and cannot be transplanted into other cultures. 


\section{Research Method}

This is normative legal research utilizing library data (library research). This research mainly uses secondary data in the form of primary and secondary legal materials. The primary legal materials are the laws and regulations that regulate the criminal liability of investigators that commit procedural errors in determining suspects during investigations, for example, the Criminal Procedure Code and the Police Law. The secondary legal materials are the views of legal experts quoted from the literature to support the thought framework and analysis of the research object, namely relevant books and the results of scientific papers such as theses, dissertations, journals, papers, and research reports. Tertiary or supporting legal materials provide directions and explanations for primary and secondary legal materials, such as general and legal dictionaries, scientific magazines, journals, and materials outside the field of law that are relevant and can be used to complement the data in this research.

\section{Results and Discussion}

\subsection{The Basis of Authority of Investigators in Determining Suspects}

Article 17 of the Criminal Procedure Code states that an individual can be declared a suspect if sufficient initial evidence is provided. However, "sufficient initial evidence" is not clearly defined. It is only defined as the initial evidence that hints at a criminal act following Article 1 point 14 of the Criminal Procedure Code. Regarding this matter, legislators leave it entirely to the investigator's assessment [11]. This does not help clarify the definition of "sufficient initial evidence". Even so, it must be obtained before determining a suspect or making an arrest [12].

As there is no specific definition contained in the Criminal Procedure Code, on March 21, 1984, four law enforcement institutions, namely the Chief Justice of the Supreme Court, the Minister of Justice, the Attorney General, and the Chief of the National Police, issued a Joint Decree as a result of the MAKEHJAPOL-I Joint Working Meeting on Improving Coordination in the Handling of Criminal Cases. One of the topics discussed was the definition of "sufficient initial evidence" as a requirement for arrest under Article 17 of the Criminal Procedure Code [13]. During the meeting, four definitions were proposed, namely: a) The police report only; b) Police report plus witness PIR/crime scene PIR/Investigation report/evidence; c) Police Report plus witness and crime scene PIR/Investigation report/evidence, and; d) Police report plus all other evidence. The meeting decided that sufficient initial evidence should be defined as a police report with one other piece of evidence regarding the four opinions.

The definition was later changed again after the Constitutional Court Decision Number 21/PUU-XII/2014 of April 28, 2015, with one of its amendments states that the phrases "initial evidence", "sufficient initial evidence", and "sufficient evidence" as stipulated in Article 1 Number 14, Article 17, and Article 21 Paragraph (1) of Law Number 8 of 1981 concerning Criminal Procedure Law (State Gazette of the Republic of Indonesia of 1981 Number 76, Supplement to the State Gazette of the Republic of Indonesia Number 3209). The definition contradicts the 1945 Constitution of the Republic of Indonesia in which "initial evidence", "sufficient initial evidence", and "sufficient evidence" are defined as having at least two pieces of evidence as contained in Article 184 of Law Number 8 of 1981 concerning Criminal Procedure Law. 
Based on the Constitutional Court Decision Number 21/PUU-XII/2014 of April 28, 2015, the initial evidence in determining a suspect is considered sufficient if the investigator possesses two valid pieces of evidence as referred to in Article 184 of the Criminal Procedure Code. The valid evidence is witness statements, expert statements, letters, instructions, and defendant statements.

According to Yahya Harahap in page 285 of the book "Pembahasan, Permasalahan, dan Penerapan KUHAP: Pemeriksaan Sidang Pengadilan, Banding, Kasasi, dan Peninjauan Kembali", Article 184 Paragraph (1) of the Criminal Procedure Code has "limitatively" defined evidence which is valid according to law. Evidence is the sole method of proving the defendant's guilt. The court chairman, the public prosecutor, and the defendant or the legal advisor are only allowed to use valid evidence. Objects outside of those defined as evidence stipulated in Article 184 Paragraph (1) of the Criminal Procedure Code cannot be used in trials and do not possess proving power.

Determining an object as evidence that possesses proving power requires specific assessment procedures. Therefore, an investigator with sufficient credibility, integrity, and professionalism is required as errors in evaluating a piece of evidence or fact can result in wrongful determination. Errors are mainly caused by unprofessionalism, insufficient skills, and a lack of integrity and credibility in performing duties. Investigators can also protect themselves by claiming procedural errors as unprocedural, which transfers the accountability to the affiliated institution.

\subsection{Criminal Liability of Investigators on Wrongful Determination of Suspects}

Criminal liability is no different from other legal subjects; they are both bound to theories of criminal liability and subject to material and formal legal principles that apply. They only differ if an investigator commits a criminal act while exercising their authority according to the law.

The concept of criminal liability is made up of the conditions needed to impose a sentence on a criminal offender. Meanwhile, based on mono dualistic ideas (daad en dader strafrecht), criminal liability not only considers the interests of the public but also those of the offenders themselves. The process depends on fulfilling the conditions, which enables the offender to be sentenced and, in turn, legalizes their conviction. According to Galligan [14], if this requirement is ignored and there are no circumstances to indicate the offender can be sentenced, then the law and its institutions have failed to fulfill their functions.

Examples of criminal acts of investigators on evidence searching include requesting information from witnesses and or suspects without following applicable procedures, falsification of PIRs, tampering with evidence, ignoring witness statements, and threatening individuals to provide or withhold information.

The law does not only apply to the public but also to law enforcers themselves. However, being law enforcement officials themselves, there are some instances in which the application of material and formal criminal law differs between citizens and investigators.

a. Formal Criminal Law

Since the police had officially separated itself from the Indonesian National Army in 2000, the criminal justice process for police officers has generally been carried out according to the procedural law in force in the general court, which is based on Law Number 8 of 1981. The process starts from the existence of a police report, investigation, prosecution until examination in court. 
Examination of criminal cases for police officers, from the investigation process to trial, is based on Law Number 8 of 1981 concerning the Criminal Procedure Code. This is contained in Article 2 of Government Regulation Number 3 of 2003 concerning Institutional Technical Implementation of General Courts for Members of the State Police of the Republic of Indonesia. It states that "In general, the criminal justice process for members of the State Police of the Republic of Indonesia is carried out under the applicable procedural law within the general court" [15].

b. Material Criminal Law

From a material law perspective, the criminal liability of investigators is different from the general public in that the sanctions being more severe. This can be seen in Article 422 of the Criminal Code Soesilo's [16] version, which states that "civil servants who in criminal cases use coercion, either to force people to confess or to lure people into giving testimony, are sentenced to four years in prison". An example of those punishable under this article is police officers who use coercion in an investigation against suspects or witnesses so that they confess or provide specific information.

During investigations, the constitution grants the police the authority to summon, examine, arrest, detain, search, and confiscate suspects and items deemed related to criminal acts. However, in exercising this authority, officers must enforce due process. Every suspect has the right to be questioned following the Criminal Procedure Code; the undue process cannot be carried out.

This issue needs to be touched upon, as there are still many complaints regarding various investigations that deviate from the provisions of the Criminal Procedure Code. In addition, the actions of investigators are very contradictory to human rights, which must be upheld during investigations. Considering the principle of legal equality, the investigator as a legal subject must be held accountable if their actions fulfill the requirements of an offense. However, as they are given the authority to enforce the law and act upon, there are several provisions of the laws and regulations that justify or excuse the actions of an investigator who commits an act that fulfills the formulation of a crime, including:

a. Carrying out the provisions of the law as stipulated in Article 50 of the Criminal Code.

b. Carrying out orders given by competent authorities as stipulated in Article 51 of the Criminal Code.

c. Carrying out an invalid order as stipulated in Article 51 Paragraph (2).

d. State of emergency (Noodtoestand). The state of emergency is part of the necessary use of force (Vis Compulsiva), stipulated in Article 48 of the Criminal Code.

e. Forced defense (Noodweer) as stipulated in Article 49 Paragraph (1) of the Criminal Code.

Based on the description above, it can be seen that an investigator who commits a procedural error can be subject to criminal liability. Of course, the subjective and objective elements of a criminal act committed by an investigator must first be analyzed.

Didik Miroharjo explains that it is possible to hold investigators criminally liable for procedural errors was about excessive use of force, even without referring to the code of ethics and disciplinary law of the police. However, this depends on the impact caused by said errors. Investigators that commit acts classified as a criminal offense, for example, wrongful arrests that result in persecution, wrongful detentions, and shooting the wrong target, must be held criminally liable ${ }^{1}$.

${ }^{1}$ Interview with Kabag Wasidik Polda Sumatera Utara, Dr. Didik Miroharjo S.H., M. Hum. on 11 March 2019 in Bag.Wassidik Ditreskrimum Polda Sumut Office 
Alpi Sahari argues that criminal liability in Indonesia must rely on the principles of due process and equality before the law to avoid abuse of power. Investigators must be held accountable for their actions to uphold the rule of law, which requires fairness. Investigators cannot be held criminally liable for violations of standard operating procedures (SOP), but it can serve as a basis for criminal liability. Examples of this include the business judgment rule and veil piercing which is aimed at implementing essential justice [17]. For this reason, it is hoped that there will be a legal reform in the Police Law concerning the criminal liability of investigators who commit errors in investigations.

From several references analyzed by the author, the indicators of procedural errors that can cause investigators to be criminally liable for excessive use of force in investigations include:

a. The use of force that does not follow procedure and can be classified as a criminal act.

b. Procedure application that is not supported by administration and field data and can be classified as a criminal act.

c. A series of procedural errors that cause the investigation to deviate from its objective and can be classified as a criminal act.

d. Procedural errors that are contrary to statutory provisions and the result can be classified as a criminal act.

e. A court decision has a permanent legal force to free a person from all charges (vrijpracht) or release someone from a legal claim (ontslag van vervolging).

\subsection{Efforts to Prevent Investigators from Wrongfully Determining a Suspect}

Efforts to anticipate procedural errors, especially in determining a suspect during investigations, are carried out through penal and non-penal policies such as:

\subsubsection{Penal Policies}

The law must be enforced against investigators who commit procedural errors in determining a suspect if their actions can be classified as a criminal act. This is a manifestation of legal equality.

To ensure that the law is enforced against investigators who commit errors, it is necessary to apply the principle of functional differentiation, namely the separation of the unit that enforces the law on investigators to prevent the functional abuse of authority. Therefore, it is necessary to establish a functional unit that deals explicitly with investigators who commit procedural errors in carrying out their duties.

The procedure for determining a suspect must be regulated in a separate law to ensure legal certainty for both the investigator and the suspect. The procedures for holding investigators criminally liable also need to be precisely regulated to ensure the legal certainty of the suspected investigator during the law enforcement process.

\subsubsection{Non-Penal Policies}

Non-penal actions focus more on prevention are indirectly carried out without using criminal law, for example:

a. Upgrading Investigators Professionalism

Police professionalism is the fundamentals of attitude, way of thinking, actions, and behavior based on police science that is realized by maintaining security and upholding truth and justice. Three parameters can be used to measure professionalism, namely motivation, 
education, and income. To produce quality law enforcers, the following principles must be fulfilled [18]:

(1) First, well-motivated. Motivation for an individual to serve as a police officer. A candidate must know and be motivated from the start because being a police officer is both a challenge and a demanding occupation. As a policeman, a person must be mentally and physically prepared and willing to serve the community. A police officer must never take half-measures;

(2) Second, well-educated. Educational standards. The police are demanded to understand the modus operandi of a crime and know the legal instruments that must be imposed on offenders. Therefore, quality police education is a necessity. The modus operandi and techniques of crime sophisticate over time. This can be countered with advanced training;

(3) Third, well-compensated. Salary is often seen as one of the keys to ensure professionalism and loyalty and prevent police misconduct. At the forefront of law enforcement, the police deserve to be well compensated. Therefore, it is necessary to improve police welfare. This can be done by granting police officers the status of functional officer, entitling them to functional allowance.

b. Education and Training

Education has a crucial role in forming the police culture in the Culture Formation Education Institution. Therefore, the police ought to pay more attention to their existence. The relationship between educators and the police should be intertwined with what Giddens called in Priyono [19] the dialectic of control. The police expect great results from educators in internalizing their normative culture to students. Likewise, the career and rank of the educators are greatly dependent on the police.

c. Improving the Facilities and Infrastructure of Investigation

The rapid development of science and technology, especially the development of information technology, has given birth to cybercrime. Criminal acts committed with technology cannot be investigated through conventional methods; high-tech equipment is needed to handle these cases. Investigating cyber crimes without utilizing up-to-date technology can potentially lead to procedural errors.

d. Integrity, Morality, and Mentality

The integrity, morality, and mentality of investigators are regulated in the Police Code of Ethics. A professional code of ethics is a demand, guidance, or moral guidance for a particular profession or a list of obligations in carrying out a profession compiled by and is binding to members of that profession. It contains ethical values that guide and control how individuals should act or behave in carrying out their profession [20].

e. Increasing Investigation Budget

The number of cases handled by investigators is far too high compared to the available budget. This is one of the potential factors that could lead to unprocedural actions.

f. Supervision and Control

The types of supervision can be classified from its scope [21]:

(1) Internal and External Supervision

A direct superior carries out internal supervision within an organizational unit. In the case of investigators, it is the Regional Investigator Profession and Security Function. External supervision is carried out by a supervisory unit outside the organization of the unit being supervised, such as supervision carried out by the National Police Commission. 
(2) Preventive and Repressive Supervision

Repressive supervision is the supervision of activity after it has been carried out. In this case, it is carried out after using force to determine whether or not it is in line with the investigation plan. This can be done as needed to identify deficiencies during official duties.

(3) Active and Passive Supervision

Close supervision (active) is carried out at the place of activity. This means that supervisors accompany investigators who use force to provide instant corrections in error. This is different from remote supervision (passive), which is done through oral or written reports.

\section{Conclusion}

Following the Constitutional Court Decision Number 21/PUU-XII/2014/ of April 28, 2015, investigators have the authority to determine a suspect if supported by two valid pieces of evidence. The principles of due process and equality before the law must be considered in determining criminal liability to avoid abuse of power. Investigators must be held accountable for their actions to uphold the rule of law, which requires fairness. They cannot be held criminally liable for violations of SOP, but they can serve as a basis for criminal liability. For this reason, there will hopefully be a legal reform in the Police Law concerning the criminal liability of investigators that commit errors in investigations.

To eliminate procedural errors in determining suspects, the recruitment process of investigators must be equipped with special education that holds professionalism, mental health, integrity, and morality to a high standard.

\section{References}

[1] M. Reksodiputro, Sistem peradilan pidana Indonesia:(melihat kepada kejahatan dan penegakan hukum dalam batas-batas toleransi). Universitas Indonesia, 1993.

[2] R. Atmasasmita, "Sistem Peradilan Pidana (Criminal Justice System) Perspektif Eksistensialisme Dan Abolisionalisme," Jakarta Bina Cipta, 1996.

[3] H. Harkrisnowo, "Rekonstruksi Konsep Pemidanaan: Suatu Gugatan Terhadap Proses Legislasi dan Pemidanaan di Indonesia," Univ. Indones. Depok, 2003.

[4] I. S. Adji, Penyiksaan dan hak asasi manusia dalam perspektif KUHAP. Pustaka Sinar Harapan, 1998.

[5] E. Djaja, "Memberantas Korupsi Bersama KPK (Komisi Pemberantasan Korupsi) di Indonesia," Bandung: Refika Aditama, 2008.

[6] English-Indonesian Online Dictionary, "Corrupt," Kamus Lengkap. [Online]. Available: https://kamuslengkap.com/kamus/inggris-indonesia/arti-kata/corrupt.

[7] P. De Cruz, "Perbandingan Sistem Hukum, Common Law, Civil Law dan Socialist Law," Bandung. Nusa Media, 2010.

[8] O. Kahn-Freund, "On uses and misuses of comparative law," Mod. L. Rev., vol. 37, p. 1, 1974.

[9] P. Legrand, "The impossibility of 'legal transplants,"” Maastrich. J. Eur. Comp. Law, vol. 4, no. 2, pp. 111-124, 1997.

[10] S. Seidman, The postmodern turn: New perspectives on social theory. Cambridge University Press, 1994.

[11] M. Y. Harahap, "Pembahasan Permasalahan dan Penerapan KUHAP: Penyidikan dan Penuntutan,” 2002.

[12] P. A. F. Lamintang and T. Lamintang, Pembahasan KUHAP menurut ilmu pengetahuan hukum pidana \& yurisprudensi. Sinar Grafika, 2010. 
[13] Joint Decree of the Chief Justice of the Supreme Court, the Minister of Justice, the Attorney General, and the Chief of the Indonesian National Police Number: 08/KMA/1984, Number: M.02KP.10.06 Th.1984, Number: KEP-076/J.A/3/1984, No Pol: KEP/04/III/1984 . .

[14] D. J. Galligan, "Due process and fair procedures: a study of administrative procedures," 1996.

[15] Article 2 of Government Regulation Number 3 of 2003 concerning Technical Guidance of General Court Institution for the Officers of Indonesian National Police. .

[16] R. Soesilo, "Kitab UU Hukum Pidana, serta komentar Lengkap Pasal demi Pasal," Politeia, Bogor, 1994.

[17] R. Bottegal, "Comments: Liberalizing Maryland's Approach to Piercing the Corporate Veil," Univ. Balt. Law Rev., vol. 42, no. 4, p. 5, 2013.

[18] Kunarto, Merenungi Kritik Terhadap Polri. Jakarta: PT Cipta Manunggal, 1995.

[19] B. Priyono \& Herry, "Anthony Giddens Suatu Pengantar," Jakarta Kepustakaan Pop. Gramedia, 2002.

[20] P. Rahardi and H. Kepolisian, "Profesionalisme dan Reformasi Polri," Laksbang Mediat. Surabaya, 2007

[21] D. Erni, "Kajian Implementasi Peraturan Perundang-undangan,” Jakarta: Kencana Fattah, 2008. 